\title{
Morte, celebração e sátira: sentido de humor e crítica social em “O defunto inaugural: relato de um fantasma," de Aníbal Machado
}

\author{
Death, Celebration, and Satire: Sense of Humor and Social Criticism \\ in "O Defunto Inaugural: Relato de um Fantasma" \\ [“The Inaugural Death: A Ghost's Story”], by Aníbal Machado
}

Diana Simões [diana_gomessimoes@uml.edu]

University of Massachusetts, Lowell, Estados Unidos da América

\section{RESUMO}

Em literatura, a morte é uma construção, a representação de um conceito abstrato. Num cenário mimético, os mortos são incapazes de falar e, certamente, incapazes de escrever livros. No entanto, vozes defuntas têm sido usadas durante séculos para contar histórias, desde a herança grega dos Diálogos dos Mortos, de Luciano de Samósata (século II d.C.), passando pelas Memórias Póstumas de Brás Cubas, do brasileiro Machado de Assis (1881), até aos nossos dias. Através da lente do fantástico, este artigo analisa o uso da narração póstuma ficcional no conto "O Defunto Inaugural," de Aníbal Machado, que desafia as convenções narrativas de verisimilitude, ao apresentar uma figura impossível de qualificar de acordo com as leis naturais. Questiono o motivo pelo qual uma voz defunta é mais apropriada para contar uma determinada história, e contesto as limitações da definição de fantástico de Tzvetan Todorov, contrapondo-as com a abordagem mais abrangente de Rosemary Jackson ao fantástico enquanto um tipo de literatura capaz de transmitir mais precisamente o estranho sentimento de deslocalização em relação a certos sistemas políticos e sociais. Sublinho o potencial da narração póstuma enquanto meio de pôr a descoberto e debater temas contemporâneos relevantes de identidade pessoal, política e social, pois, enquanto figura transcendente, este defunto tem a autoridade de revelar a verdade e confessar segredos. A morte proporciona uma plataforma segura para contar um lado da história que tinha mantido em silêncio enquanto estava vivo.

\section{Palavras-Chave}

Narração Póstuma; Fantástico; Unheimlich; Abjeção; Morte.

\begin{abstract}
Death in literature is a construction, a representation of an abstract concept. In a mimetic scenario, dead people are unable to speak and, certainly, unable to write books. However, dead voices have been used for centuries to tell stories, since the Greek heritage of Lucian of Samosata's Dialogues of the Dead (II century) to Machado de Assis's Brazilian novel The Posthumous Memoirs of Brás Cubas (1881), all the way into the twenty-first century. Through the lens of the fantastic, this article analyses the use of fictional posthumous narration in the short story "O Defunto Inaugural" ["The Inaugural Death"], by Aníbal Machado, which challenges the narrative conventions of verisimilitude by presenting an impossible character according to the
\end{abstract}


laws of nature. I question the overall reason a dead voice is more appropriate to tell a particular story, and challenge the limited scope of Tzvetan Todorov's definition of the fantastic by contrasting it with Rosemary Jackson's broader approach to the fantastic as a type of literature productive in conveying the uncanny feeling of displacement in relation to certain social and political systems. I highlight the potential of posthumous narration as a means to uncover and discuss relevant contemporary issues of personal, political, and social identity, because, as a transcendent figure, this dead man has the authority to speak the truth and reveal secrets. Death provides a safe space to tell a side of the story that they kept silent while alive.

\section{KEYWORDS}

Posthumous Narration; Fantastic; Unheimlich; Abjection; Death.

RECEBIDO 2019-04-20; ACEITE 2019-06-30

\section{Cadáveres, Defuntos e Vozes Póstumas}

Em literatura, a morte é uma construção, a representação de um conceito abstrato. Elisabeth Bronfen e Sarah Goodwin argumentam, em Death and Representation (1993), que qualquer representação da morte é, invariavelmente, uma distorção: nenhum defunto alguma vez ressuscitou para contar a sua história. Os mortos são incapazes de falar e, certamente, incapazes de escrever livros. Nesse sentido, as construções culturais em torno da morte são tentativas de, simultaneamente, representá-la e fazer a sua contenção, de torná-la compreensível e de dissipar algum do seu poder (Bronfen e Goodwin 1993: 4). O cadáver provoca a estranheza que Sigmund Freud denomina Unheimlich, pois a sua presença ocupa simultaneamente dois espaços, o aqui e o lugar nenhum: não faz parte deste mundo e não está inteiramente ausente dele. O cadáver faz a mediação entre estas duas posições incompatíveis, e a estranheza emerge porque o corpo se parece consigo mesmo, tornando-se, assim, no seu próprio duplo (Bronfen e Goodwin 1993: 12).

Vozes defuntas têm sido usadas durante séculos para contar histórias, desde a herança grega dos Diálogos dos Mortos, de Luciano de Samósata (século II d.C.), passando pelas Memórias Póstumas de Brás Cubas, do brasileiro Machado de Assis (1881), até aos nossos dias. No Brasil, Machado de Assis tornou famosa a temática da narração póstuma em língua portuguesa, com a publicação, em 1881, do seu romance Memórias Póstumas de Brás Cubas. Aí, o autor apresenta-nos um narrador defunto que deseja escrever a sua autobiografia, sem deixar de fora as cerimónias fúnebres e os acontecimentos que levaram à sua morte, bem como todas as peripécias que viveu. No romance, a narração autobiográfica é veículo para temas mais abrangentes e problemáticos, que incluem a escravatura ou a degradação social, política e filosófica vivida no Rio de Janeiro de finais do século XIX. Sobre Brás Cubas e a sua obra, afirma Alice Bennett que a publicação de um livro de memórias póstumas assume a inclusão de segredos indizíveis entre os vivos. Brás Cubas acredita que a sua história de vida contada depois da sua morte tem mais autoridade e, assim, se transforma na derradeira forma de autobiografia (Bennett 2012: 149). Brás Cubas intitula-se “defunto-autor," isto é, um homem que já morreu e que deseja escrever a sua autobiografia - o oposto de "autor-defunto," que implicaria ter sido escritor em vida. Esta 
distinção é determinante, porque a morte oferece vantagens a um narrador inclinado a expor e dissecar não só as suas incongruências morais e psicológicas, mas também as dos seus pares (Moser 2004: 97).

Tal como argumenta Erwin Snauwaert, o narrador póstumo possui uma grande capacidade crítica advinda do seu distanciamento físico, espacial e temporal. E se, como continua o autor, a morte transforma o narrador numa figura de autoridade que assina um contrato de autenticidade e se compromete a garantir a veracidade do relato (Snauwaert 2013: 188-92). Enquanto figuras transcendentes, têm a autoridade de revelar a verdade e confessar segredos. A morte proporciona uma plataforma segura para contarem um lado da história que tinham mantido em silêncio enquanto estavam vivos. Sublinho o potencial da narração póstuma enquanto meio de pôr a descoberto e debater temas contemporâneos relevantes de identidade pessoal, política e social. Na ficção, as memórias póstumas e a narrativa que invoca os mortos desenrolam-se desimpedidas das amarras da realidade empírica, ultrapassando o reino da verosimilhança e satisfazendo a nossa necessidade de atingir o impossível: a narração da nossa própria morte (Moser 2008: 266).

Os defuntos contadores de histórias cativam a nossa atenção, pois queremos ouvir o que têm para nos dizer. A minha pesquisa pressupõe que a condição póstuma permite uma nova perspetiva sobre os acontecimentos narrados, dada a distância temporal e espacial do mundo dos vivos. Por essa razão, os mortos apresentam uma vantagem epistemológica, porque se observam não apenas a si próprios e à sua vida terrena que terminou, mas observam igualmente outras personagens de forma íntima e detalhada. Os mortos que nos contam as suas memórias fazem-no com consciência de uma liberdade de expressão (negada em vida) que lhes permite a possibilidade da confissão de segredos sobre si e sobre as outras personagens. A narração póstuma servirá o propósito da reescrita pessoal, social e histórica no contexto específico da lusofonia, com revelações cujo intento é o de mudar a forma de nos pensarmos, de pensarmos a história e as sociedades em que estes narradores póstumos se inserem - estas poderão ou não coincidir com o espaço e tempo dos leitores. A marginalidade dos narradores póstumos servirá também como estratégia de empoderamento de certos elementos da sociedade que, em vida, experienciaram opressão; após a morte, ficam libertos para contar a sua verdade. Enquanto leitores e leitoras, beneficiamos do conhecimento que nos querem transmitir, porque, como afirma Thomas W. Laqueur, os vivos precisam dos mortos muito mais que os mortos precisam dos vivos (Laqueur 2015: 1).

\section{Aníbal Machado e A Morte da Porta-Estandarte e Tati, a Garota e Outras Histórias}

Aníbal Machado (1894-1968) é um renomado autor brasileiro, criticamente prestigiado pelo seu trabalho contístico e ensaístico. Natural de Sabará, Belo Horizonte, onde passa toda a infância, começa o curso de direito no Rio de Janeiro, terminado posteriormente na sua cidade natal. Regressa de novo ao Rio, em 1923, onde a sua residência passa a ser ponto de encontro dos maiores nomes ligados ao modernismo nas áreas da literatura, das artes plásticas e do teatro. O seu empenho intelectual e partidário reflete-se na participação na segunda fase do movimento antropofágico, 
liderado por Oswald de Andrade1. Em 1944, é eleito presidente da Associação Brasileira de Escritores e organiza, no ano seguinte, com Sérgio Milliet, o Primeiro Congresso Brasileiro de Escritores, em São Paulo. Desse evento resultou a "Declaração de Princípios" contra a ditadura de Getúlio Vargas, em colaboração com vários autores, onde se defende "a legalidade democrática como garantia de completa liberdade de expressão do pensamento, da liberdade de culto, da segurança contra o temor da violência, e do direito a uma existência digna" (Machado 1982: vii, nota da editora). O regime do Estado Novo brasileiro, liderado por Getúlio Vargas, foi deposto em 1945. A posterior redemocratização do país, com a adoção de uma nova constituição em 1946, marca o fim da Era Vargas e o início do período conhecido como Quarta República Brasileira. As reivindicações sociais são uma constante nos seus contos, como poderá ser constatado posteriormente neste artigo.

Na introdução ao volume de contos Morte da Porta-Estandarte e Tati, a Garota e Outras Histórias (1965), onde se insere o conto que analisarei, "O Defunto Inaugural," M. Cavalcanti Proença exalta o universalismo da obra de Machado e a "perícia artesanal e artística" (Proença 1982: xi) dos seus textos, que rapidamente se tornaram clássicos para o ensino da técnica literária. Proença destaca também a ironia como uma das constantes dos textos do autor. A sua ficção é, no entanto, difícil de contextualizar, pois a obra apresenta, ao mesmo tempo, características surrealistas, sem nunca deixar de ter uma estrutura bem delimitada: a fantasia e a realidade passam a ser uma e a mesma coisa, interpenetrando-se e esbatendo os limites entre as duas. A narrativa vive em "terreno fronteiriço," entre o "chão da realidade" e as "nuvens do imaginário" (Proença 1982: xii). A imaginação alia-se ao raciocínio, sempre de forma equilibrada - Proença refere-se a ela como "balões cativos pelos quais se processa uma incursão no espaço imaginativo e onírico, sem desfixar do solo as amarras de um espírito crítico atento, anti-romântico, mas sorridente" (Proença 1982: xxvi). O narrador póstumo d"“O Defunto Inaugural" vive neste "terreno fronteiriço" entre duas realidades, pois o seu corpo já sem vida, manipulado por outros para proveito próprio, ficou no chão da realidade terrena, enquanto os seus fluidos espirituais vagueiam num plano distinto pertencente às nuvens do imaginário.

Um dado notável da biografia de Aníbal Machado é a sua ligação ao futebol: foi, durante três anos, jogador do Clube Atlético Mineiro e, em 1909, marcou o primeiro golo da história do clube. O futebol aparece também na sua ficção, precisamente no conto "O Defunto Inaugural," em que um grupo de rapazes de Arraial Novo treina para um campeonato com a equipa vizinha, no espaço destinado ao futuro cemitério do povoado. O campo de futebol transformado em cemitério vai ser o espaço central da narrativa, onde convergem todos os conflitos do conto, explorado de seguida.

\section{3. “O Defunto Inaugural: Relato de um Fantasma”}

O tropeiro Fagundes relata a acidentada viagem empreendida pelo seu corpo sem vida, por mãos de dois homens que o encontraram na estrada e viram nele a oportunidade de uma recompensa

1 O movimento antropofágico foi uma manifestação artística brasileira dos anos 20 do século XX, fundada por Oswald de Andrade e tematizada no seu "Manifesto Antropófago." Este movimento tinha por objetivo assimilar (comer) a cultura do outro, quer esse outro fosse estrangeiro (Europa, Estados Unidos), quer fosse nacional (ameríndios, afrodescendentes), mas sem a imitar. 
monetária. Caminham rumo a Arraial Novo, um povoado que decide comprar um defunto digno de inaugurar o cemitério ${ }^{2}$. A causa da sua morte não é revelada; porém, o narrador relata a facilidade de encontrar defuntos a apodrecer pelos caminhos por aquelas terras abandonadas, onde só passam camiões. Fagundes descreve de forma jocosa, da sua posição privilegiada de defunto inaugural, as forças em conflito no povoado: os rapazes, que ambicionavam apenas continuar a jogar futebol no terreno do cemitério, adotado como campo; o Fundador, patriarca ilustre e dono de quase tudo, que mandou construir o cemitério, apesar de se manter afastado de qualquer assunto relacionado com a morte; e as mulheres da terra, que inventaram a necessidade de um cemitério e sua devida inauguração, e cumprem com devoção o ritual de chorar os mortos, mesmo os desconhecidos. Os antagonismos das relações sociais são postos a descoberto pela voz póstuma de Fagundes, agora livre para ridicularizar e desconstruir o delicado equilíbrio de poderes de Arraial Novo.

Sabemos, desde o início do conto, que a história é narrada por um defunto - a dissipação da incerteza não permitiria considerar esta obra como pertencente ao fantástico, de acordo com a conceção restrita do género por Tzvetan Todorov (1973); pertenceria, sim, ao maravilhoso ${ }^{3}$. No entanto, no contexto mais abrangente das definições de fantasia de Ana María Barrenechea (1972), Rosemary Jackson (1981) ou Cynthia Duncan (2010), a história permanece como uma narrativa do fantástico, pelo confronto entre a ordem da verosimilhança e a da fantasia, devido à inclusão, num cenário mimético, de um elemento inexplicável pelas leis regentes do mundo natural: um defunto contador de histórias.

Fagundes apresenta-se como um defunto com a capacidade, na sua condição de espírito sem corpo, de interagir física e psicologicamente com as personagens vivas, por oposição a outros narradores póstumos, como Brás Cubas (Machado de Assis, Memórias Póstumas de Brás Cubas, 1881), um observador não interferente no mundo dos viventes. Nesse sentido, apresenta-se como uma variação de um determinado tipo de fantasma, o poltergeist. Na definição-padrão, poltergeist é uma entidade sobrenatural responsável por distúrbios físicos como barulhos assustadores ou objetos violentamente movimentados ${ }^{4}$. No entanto, a intenção de Fagundes consiste apenas em fazer as personagens agirem de acordo com os seus desejos. Fá-lo quando influencia os homens que o carregam a seguir pela estrada nova - "Tal como eu queria” (Machado 1982: 48) -, quando lhes ordena que engulam depressa a cachaça para continuarem a marcha antes de escurecer, ou

2 Existe, de facto, uma comunidade em Minas Gerais com o nome de Arraial Novo, pertencente ao município de Bambuí, relativamente próxima da Serra da Canastra. É incerto se esta terá sido a inspiração para o espaço de Arraial Novo do conto de Machado, mas fica a certeza da ligação entre os seus textos e a sua origem geográfica.

3 Uma vez que o fantástico ocupa apenas a duração do tempo da hesitação, Todorov prevê três possibilidades de solução para os eventos obscuros - o leitor toma uma decisão em relação à história, mesmo que a personagem não o faça. Numa primeira possibilidade, se o leitor escolhe uma explicação lógica para os fenómenos, a lei da realidade mantém-se intacta e a obra resolve-se no estranho. Explicações lógicas incluem sonhos, coincidências, influência de drogas, doença mental, ou ilusão dos sentidos. Se, em segundo lugar, quem lê decide aceitar o sobrenatural, novas leis que não as do mundo natural são necessárias para explicar os eventos, e a história passa a fazer parte do maravilhoso. Por ser um género evanescente, o fantástico encontra-se na fronteira entre estes dois. Existe, no entanto, uma terceira opção: porque certos textos mantêm a ambiguidade até ao final, não oferecendo explicação para os fenómenos fora do normal, a dúvida pode persistir mesmo após o fim da leitura - nesse caso, entramos no reino do fantástico puro (Todorov 1973: 41-43.).

4 De acordo com o dicionário Oxford, o termo poltergeist teve origem no século XIX. A palavra é de origem alemã e deriva da junção dos termos poltern (criar distúrbio) e geist (fantasma). Poltergeist é também o título de um filme de 1982, com direção de Tobe Hooper e guião de Stephen Spielberg. 
quando "grita" ao careca para sacudir a varejeira da testa. A sua "voz não ressoa, mas produz efeito" (Machado 1982: 49), os seus gritos inaudíveis são, de alguma forma, escutados.

Já em Arraial Novo, na noite do velório anterior ao funeral, o "defunto imenso e difuso" (Machado 1982: 53) vagueia pelo povoado, fazendo os cães ganir e afastando os curiosos das janelas, por medo de um potencial encontro com o fantasma do homem a enterrar no dia seguinte. $\mathrm{O}$ narrador penetra na intimidade dos lares e observa a simplicidade das gentes, tocando-lhes na nuca e provocando um estremecimento inexplicável e aterrador. No entanto, a sua força não é suficiente para apagar lamparinas, porque os seus fluidos estão a enfraquecer. A razão desse enfraquecimento é a conexão entre corpo e espírito: se um se desintegra, o outro segue-se-lhe. Apesar de fraco, tem ainda força suficiente para interceder pelos casais que se encontram clandestinamente no dia do funeral, segredando a uma moça para deixar o namorado apertá-la - "Parece que a moça me entendeu” (Machado 1982: 54). As carícias do espírito malandro provocam nas moças arrepios e enrubescimento; elas sentem a necessidade de esconder o busto com os braços ou o xaile, sem saberem explicar porquê, quando os fluidos do narrador lhes roçam o colo. Apesar de morto, o desejo sexual não o abandona.

Os dias são cada vez mais tristes e solitários, sem ninguém que lhe faça companhia no cemitério, e os seus fluidos vão enfraquecendo. Ganha, porém, novo ânimo quando os rapazes passam a invadir o terreno, saltando o muro, para continuar a jogar futebol às escondidas, durante a noite (apesar da proibição da professora). O narrador espera ansioso por esses encontros, chamando os rapazes, mesmo sem garganta e sem voz. Confessa aos leitores ser ele quem soprava no apito do árbitro, chegando a provocar discussões entre os rapazes - "intervinha sem que ninguém soubesse, só para animar" (Machado 1982: 57). Depois de a professora descobrir o que o grupo anda a fazer, a vigilância é redobrada, e o defunto volta a ficar sozinho, perdendo quase completamente todas as forças: "A paisagem se dissolve ao meu olhar que está se apagando" (Machado 1982: 58). No final, a sua missão cumpre-se quando surge um novo espírito para habitar o cemitério, e pode finalmente desvanecer-se.

O tropeiro Fagundes faz parte da extensa lista do que Moser chama "defuntos carnavalescos," cuja principal função consiste na crítica social. De acordo com este autor, a tradição brasileira do defunto carnavalesco teve início com a publicação de Memórias Póstumas de Brás Cubas, em 1881. Estes defuntos são usados como estratégia retórica de comentário sociopolítico, expondo tensões e fissuras no seio da sociedade em que se inserem (Moser 2004: 6). No conto de Machado, o narrador começa por queixar-se dos "caminhões enormes que começam a invadir a serra depois que se abriu a estrada que vira para a encosta de la” (Machado 1982: 48). Na página seguinte, refere-se à bomba de gasolina como "mancha de sangue na vegetação" (Machado 1982: 49). Fagundes rejeita estes símbolos do progresso, pela agressividade com que destroem a natureza até então em estado quase virgem. A referência ao sangue implica consequências para o espaço: os esforços de industrialização estão a provocar feridas mortais nos ermos. O tom é amargo, porque o advento das estradas e dos camiões vem pôr fim à atividade profissional desempenhada em vida, o tropeirismo.

Antes da construção de estradas e do uso de camiões, os tropeiros tinham sido, durante séculos, figuras proeminentes na economia de Minas Gerais. A função do tropeiro baseava-se no transporte de toda a espécie de mercadorias, carregadas em mulas, percorrendo os muitos quilómetros de terreno acidentado que separavam os pequenos povoados isolados do interior, sem acesso às cidades grandes. Estas regiões rurais dependiam inteiramente do tropeirismo para a circulação 
de bens e de notícias. Assim, percebe-se o porquê da severa crítica à vinda das máquinas, não só pelo próprio tropeiro, mas também pelo vereador distrital, aquando do seu discurso no enterro inaugural: o tropeiro é uma "raça que se extingue ante a avançada progressista dos caminhões" (Machado 1982: 55). O ganha-pão do narrador estava em vias de extinção, ao ponto de ser cada vez mais frequente encontrarem-se defuntos apodrecendo pelos caminhos. Sem trabalho e sem perspetivas de futuro, estes homens dedicam-se à bebida e à deambulação sem destino certo e, ou são atropelados pelos camiões, ou morrem de frio, devido às duras condições climáticas do sertão. Apesar de Fagundes nunca dizer como morreu, esta poderá ter sido uma das possibilidades, porque o seu corpo curtido pelo sol fora encontrado pelos homens que o transportam para Arraial Novo, na berma de uma estrada, completamente abandonado - um deles afirma ter sido "morte de Deus" (Machado 1982: 50), por oposição a um potencial crime.

Habituado a lidar com compra e venda de toda a espécie de bens, um tropeiro encontrado pelos dois homens no caminho sabe apreciar a "qualidade da mercadoria" (Machado 1982: 49) em carga. Diana Fuss explica, em "Corpse-Poem," como a dessacralização da morte tinha convertido o cadáver em item comercial que podia ser comprado ou vendido, tal como qualquer outro tipo de mercadoria (Fuss 2003: 3-4). O corpo de Fagundes está em bom estado de preservação, com as carnes curtidas como uma múmia, colocando-o em vantagem em relação aos outros defuntos da competição para inaugurar o cemitério de Arraial Novo. E, apesar da experiência de manipular uma grande variedade de bens de consumo, o tropeiro mostra-se incrédulo com a situação: "Comprar defunto pra cemitério, foi coisa que nunca vi" (Machado 1982: 49). Nesta altura, Fagundes finalmente entende o porquê da pressa dos homens e o do transporte: "fizeram cemitério nalgum lugar, mas faltou defunto para inaugurá-lo" (Machado 1982: 49). Ainda não sabe onde, mas o seu espírito competitivo quer ganhar a corrida contra os outros defuntos. Dois interesses estão em jogo: "O interesse dos que me carregavam era chegar primeiro e negociar depressa os despojos; o meu, era ganhar a corrida com o colega que ia na frente" (Machado 1982: 50). E ganha, de facto, a corrida, porque o primeiro colega a chegar a Arraial Novo estava em tal estado de decomposição que não foi o escolhido como defunto inaugural.

A materialidade dos corpos mortos remete para a abjeção, segundo Julia Kristeva - o cadáver está no centro do que a autora considera abjeto. Em Powers of Horror, apresenta o corpo sem vida, em decomposição, como o símbolo máximo de abjeção, pois a morte infecta a vida; não é possível distanciarmo-nos nem protegermo-nos dela. O cadáver provoca abjeção, porque perturba a identidade, o sistema, a ordem: representa aquilo que não respeita os limites e as regras (Kristeva 1982: 4). A matéria em decomposição daquilo que outrora fora humano é substância inquietante que precisa de ser excluída do espaço e do discurso (Kristeva 1982: 109). No entanto, ao contrário dos colegas da competição, que estão catingando (cheirando mal), a "carcaça" do narrador do conto de Machado continua em ótimo estado, "nem tá cheirando" (Machado 1982: 50). A corrida descontrolada de defuntos é um dos momentos cómicos do conto, ao ponto de o dono de uma estalagem dizer, indignado, que chovem defuntos pela encosta abaixo. Já em Arraial Novo, o corpo de Fagundes não provoca qualquer estado de inquietação, sendo recebido em apoteose e festa por um bando de crianças e um cão, que o rodeiam e fazem troça do seu dente único - o facto de ter um único dente pode ser lido como indicador de uma condição social e económica desfavorecida, sem meios para cuidar da saúde oral devido a uma vida de itinerância em regiões do interior do país afastadas de centros médicos. Contudo, o mesmo não acontece com os outros cadáveres, 
representantes do que Kristeva identifica como abjeto. O primeiro cadáver a chegar estava largado nas escadas da igreja, e as crianças, de lenço no nariz, tropeçam num "fardo que cheirava mal" (Machado 1982: 51), para em seguida verem um terceiro concorrente deitado numa carrocinha. Isso provoca a indignação e a revolta dos rapazes - reclamam da "invasão do Arraial por gente podre" (Machado 1982: 51), argumentando que os cadáveres em decomposição iriam causar uma epidemia, pois o cadáver, fonte de impureza, exige a necessidade de purificação. Depois das queixas dos rapazes, os dois corpos em decomposição são prontamente enterrados, ficando assim os cadáveres (causas da abjeção) afastados do contacto com os viventes. Pode-se, no entanto, fazer uma pergunta, que nunca terá resposta no texto: onde foram enterrados estes cadáveres podres? Não no cemitério, ou a criação de um defunto inaugural já não faria sentido, porque não seria o primeiro morto a ser enterrado nesse espaço. E se não foram enterrados no cemitério, então não receberam os ritos fúnebres cristãos de que tanto se orgulha o povoado. Estes corpos são tratados como mercadoria descartável que não serve os propósitos das mulheres, e pode, por conseguinte, desaparecer.

O cadáver de Fagundes não partilha das características abjetas dos seus colegas e está apto, portanto, a passar por todos os rituais fúnebres que o transformarão no primeiro defunto a ser enterrado no novo cemitério. Todos os ritos funerários administrados a Fagundes pertencem ao imaginário judaico-cristão. Quando chega, o narrador é colocado em lugar de destaque, num estrado no centro da igreja, a sua cara é destapada (por oposição aos corpos em decomposição, que precisavam de estar totalmente cobertos), e uma velha ajoelha-se a rezar, presumivelmente pela sua alma. Então faz sentido que, havendo uma igreja no povoado, haja também um cemitério, pois os dois espaços estão interligados e devem funcionar em conjunto ${ }^{5}$. Um não opera sem o outro, daí a urgência das mulheres em pressionarem o Fundador para a construção do cemitério. Sem este espaço específico, um ciclo não se completa, e a sua utilização para atividades lúdicas, como os jogos de futebol das crianças, não é religiosamente aceitável para este grupo de mulheres. As beatas insistem na sacralidade do espaço onde enterrar os futuros mortos.

Depois de a carcaça do narrador ser aprovada, e a transação com os carregadores completa, as velhas (termo usado pelo narrador, e que manterei para me referir às mulheres) iniciam o processo de lavar e vestir o defunto; este elogia a transformação sofrida: "Fiquei um defunto bem passável” (Machado 1982: 52), limpo e bem-trajado (por oposição aos farrapos usados quando o seu corpo foi encontrado). Os sinos repicaram, anunciando tardiamente a morte do narrador (toque de finados) e o funeral do dia seguinte. Segundo a tradição, o corpo deve ser velado por aqueles que lhe são próximos. Neste caso, Fagundes estava entre dois grandes círios acesos, rodeado de "mulheres que rezavam ou fingiam rezar" (Machado 1982: 53). O fingimento vai permear toda a existência do narrador em Arraial Novo; sendo um defunto anónimo, as mulheres que o choram não o conhecem; estão apenas a cumprir as formalidades dos ritos fúnebres. O narrador ganha uma nova identidade, por comparação com quem foi em vida, para melhor se adequar ao seu papel e estatuto de defunto inaugural.

5 Durante séculos, os mortos de uma comunidade cristã eram enterrados nos adros das igrejas, beneficiando assim da proteção de um local sagrado. Em The Work of the Dead, Laqueur traça o percurso da exclusividade dos cemitérios apenas para a comunidade da paróquia até à sua abertura a todos aqueles que pudessem pagar funeral, a partir de 1800 , bem como a sua deslocação para um local afastado da igreja. O estudo de Laqueur tem um foco na cultura europeia e, mais concretamente, na inglesa, mas as suas conclusões podem também ser aplicadas ao contexto brasileiro do conto de Machado. 
A teatralização do enterro atinge o auge com a professora, com um ar doloroso preparado para o momento em que Fagundes chega à igreja pela primeira vez. Ela comporta-se, desde o início, como se fosse a viúva do falecido - era a "dona do enterro" (Machado 1982: 52) e do cemitério, porque tinha a chave à sua guarda, e os portões só seriam abertos quando fosse chorar o seu defunto. Depois do momento de descer o corpo à sepultura, acompanhado das palavras do padre em latim, a "viúva" chora sobre a campa enquanto murmura "José, meu José" (Machado 1982: 56). Fagundes sempre achara suspeita a forma como a professora olhava para ele; enquanto narrador defunto observando de forma distanciada do mundo dos vivos, vai exercer o seu papel de repositor da verdade: desmente chamar-se José (apesar de já ter esquecido o seu nome). José poderá ter sido alguém que a professora efetivamente perdera e não tivera a oportunidade de chorar enquanto viúva legítima. Apesar de não se saber quem era José, o narrador converte-se nessa figura com necessidade de um enterro solene, de forma a solucionar o conflito interior de uma mulher desconhecida no papel de sua viúva. De acordo com Katherine Verdery, em The Political Lives of Dead Bodies, o cadáver, os ossos, os caixões e as urnas de cremação são objetos que representam a materialidade do corpo, o que muito contribui para a sua eficácia simbólica: um cadáver pode ser deslocado, exibido ou estrategicamente posicionado em locais específicos (Verdery 1999: 26). Fagundes obtém uma nova identidade à sua revelia; testemunha o transporte, manuseamento e exibição do seu corpo com fins distintos, de acordo com a necessidade daqueles envolvidos na criação simbólica do defunto inaugural: os carregadores veem nele uma fonte de lucro; as mulheres transformam-no no filho da terra com a honra de ser o primeiro corpo enterrado no novo cemitério; e a professora transfere os seus afetos perdidos para este defunto a que chama José (possivelmente o nome do homem por quem chora de verdade).

Apesar de estar descontente com o toque de finados, classificado como "batucada confusa e sem ritmo" (Machado 1982: 54), Fagundes constata que a população cumpre o seu papel e age decentemente, acompanhando o cortejo fúnebre da igreja até ao cemitério. Contudo, depois de cumpridos os solenes ritos, chega a hora de celebrar. Fagundes é um dos defuntos carnavalescos de The Carnivalesque Defunto, de Moser, pela relevância, no conto, do ambiente celebratório. Até o próprio defunto se contagia com o entusiasmo dos habitantes nos preparativos: "o enterro valeria a pena como festa” (Machado 1982: 53). O enterro é considerado pela população um evento social importante, para o qual todos se preparam com pompa. Este comportamento assemelha-se ao de outras pequenas cidades do interior de Minas Gerais: os funerais "representam o reflexo de uma população unida, o rito fúnebre é um momento de efervescência, primeiramente por gerar movimento em uma localidade de vida pacata" (Tavares 2012: 98). O narrador revela que, sob a aparência fúnebre, as mulheres tentam esconder o seu entusiasmo e, no final, nem conseguem chorar, tal é o frenesi do júbilo de toda a população estar reunida para um mesmo fim. As mais entusiasmadas com o funeral não são as mulheres mais velhas, mas as moças novas, que preparam os seus melhores vestidos e se arranjam para o cortejo. As jovens sabem que esse será um pretexto para poderem encontrar-se clandestinamente com os rapazes da aldeia, os atletas futebolísticos do cemitério. Uma vez que as mães estão ocupadas com os preparativos do funeral, a vigilância não será tão apertada, e podem namorar em segredo - o narrador, na qualidade de observador e voyeur, aprova e aprecia estes encontros, sua única alegria num estado que já não lhe permite o contacto físico sexual com um corpo feminino. 
No final do enterro, todos se abraçam e despedem felizes, com um sentimento de missão cumprida: o cemitério estava devidamente inaugurado e pronto para receber os futuros mortos do povoado. O narrador era agora, oficialmente, o primeiro defunto enterrado no novo espaço, o chamariz para os mortos que hão de vir, "como ovo de indez" (Machado 1982: 56) ${ }^{6}$. O cemitério torna-se no lugar preferido das velhas, que "rezam pelo futuro defunto, rezam para a morte" (Machado 1982: 56). De facto, até à chegada de Fagundes, a morte era uma realidade desconhecida em Arraial Novo. O narrador comenta que, aquando da sua chegada, um grupo de curiosos se reuniu à sua volta, porque viam um defunto pela primeira vez. Apesar de o conto começar por apresentar aos leitores à fantasia de um narrador defunto que vai inaugurar um cemitério, existe uma ligação à realidade extratextual através da menção do progresso invasor, com as novas estradas e camiões. Porém, é necessário questionar a verosimilhança do espaço para onde os carregadores transportam o corpo do narrador. Esta é uma instância do que Sigmund Freud define por Unheimlich - algo que é, ao mesmo tempo, estranho e familiar: não é nada de novo, mas algo familiar e já estabelecido na mente, e que se transformou em estranho pelo processo de repressão (Freud 1997: 195). O povoado poderia existir nos sertões de Belo Horizonte, a sua estrutura é-nos familiar; contudo, algo estranho nos inquieta: que sítio é este onde ninguém, até então, tinha visto um defunto? Será que, em Arraial Novo, ninguém morre?

Depois de finalmente inaugurado o cemitério com o cadáver de Fagundes/José (marido da professora), o narrador comenta a mudança de atmosfera em Arraial Novo: todos viviam agora silenciosos e tristes, ocupando-se a população em "interrogar a alma" (Machado 1982: 57). O Fundador não tem dúvidas: as mulheres inventaram a morte no povoado, foram as responsáveis pelo silêncio e tristeza que se abateram sobre os moradores. A morte está presente em todos os níveis da existência diária (Bronfen 1992: 54) em Arraial Novo, consciente ou inconscientemente. Infere-se que a preocupação com a morte teria sido, para estas mulheres, uma constante inquietação; esta preocupação sempre existira, apesar de ter estado silenciada por muito tempo. A construção do cemitério foi uma forma de externalização e materialização da angústia com a morte - esta é apaziguada pela existência do novo espaço no povoado.

O Fundador de Arraial Novo ilustra a figura patriarcal por excelência, por ser um "velho robusto, três vezes casado, figura principal e dono de quase todo o lugar, que enchera de filhos e netos" (Machado 1982: 51). Assume-se como a pessoa mais poderosa do povoado que ergueu trinta anos antes; contudo, o narrador mostra quem verdadeiramente exerce o poder. São as mulheres que impõem a sua vontade de transformar o local de treinos de futebol dos rapazes no recinto murado do cemitério. Na hierarquia de poderes de Arraial Novo, os meninos estão em desvantagem. Dona Maria, esposa do Fundador e a única pessoa com alguma influência sobre o marido a quem poderiam apelar, está doente, de cama, e começa a dar sinal de dores de parto. Esta mulher, mencionada apenas uma vez durante toda a narrativa, ganhará o seu momento de protagonismo póstumo no fim do conto - a sua aparente insignificância discursiva é posteriormente revertida pelo narrador.

O cemitério é, portanto, da inteira responsabilidade das mulheres. O Fundador, pelo contrário, quer manter-se afastado de todos os assuntos ligados à morte: "Eu, por mim, quando chegar a minha hora, vou morrer sozinho lá em cima, no mato" (Machado 1982: 51). Subiu ao monte na

6 O ovo de indez é o que se deixa no galinheiro depois de recolher todos os outros, para que as galinhas continuem a pôr ovos sempre no mesmo lugar. O termo "indez," originário de Minas Gerais, é a forma oral abreviada de "um deles" (um dos ovos). 
altura do enterro de Fagundes e não compareceu ao funeral-festa. Este distanciamento pode ser lido como uma atitude cobarde e demonstração do vazio do seu poder, pois não consegue contrariar as mulheres, mesmo depois de ter ouvido as vozes da razão protestando contra a construção do cemitério. Porém, esses argumentos lógicos são apresentados pelas crianças, um grupo sem qualquer poder influenciador na sociedade de Arraial Novo.

A aparência de poder está representada também na personagem do vereador distrital, figura pública respeitável que prestigia a inauguração do cemitério com a sua presença e discurso público. Na homenagem ao defunto inaugural, afirma tê-lo conhecido pessoalmente e descreve-o como "um dos últimos tropeiros do nosso amado sertão" (Machado 1982: 55), nascido e criado em Arraial Novo. O ponto de vista póstumo do narrador permite-lhe denunciar e criticar a falsidade das palavras do vereador, restabelecendo a verdade: "onde? como? se nunca me viu, se nunca votei!" (Machado 1982: 55) - por todos os factos já apresentados pelo narrador, acreditamos nesta sua correção. Este trata-se de mais um elemento de teatralidade no espetáculo do enterro: o vereador assume o seu estatuto de poder em público; contudo, a sua vida pessoal, que deveria ser do foro privado, acaba ridicularizada em público, num diálogo entre o coveiro e a professora, presenciado pelo narrador defunto. Quando a professora indaga quem teria chutado a bola para dentro do cemitério e derrubado a cruz da campa, o coveiro lembra-se de Zequinha, que fugiu com a mulher do vereador - "Jogava tão bem, que ela fugiu com ele" (Machado 1982: 58). As suas qualidades não são tanto o saber jogar bem no campo, mas saber fazê-lo na cama. Implícito fica que o vereador não consegue satisfazer sexualmente a mulher, o que constitui um ataque à sua virilidade e, portanto, debilita a sua autoridade de figura pública.

Tudo em Arraial Novo é uma ilusão fabricada: persiste a necessidade de criar uma existência que se encaixe nas convenções de funcionalidade e organização estrutural das cidades vizinhas: governo local (cumprido pelo Fundador), espaço de ensino (a escola onde os rapazes têm aulas e onde a professora é senhora absoluta), espaço religioso (igrejinha com um padre que diz a missa e confessa as mulheres) e, por fim, um cemitério para enterrar os futuros mortos - espaços principais para Arraial Novo deixar de existir numa fantasia de imortalidade, insustentável do ponto de vista das mulheres. Um consultório médico não é a maior prioridade para o funcionamento do povoado, pois os médicos estão disponíveis na cidade mais próxima. O novo cemitério funciona como uma espécie de âncora: o ficcional Arraial Novo legitima-se, finalmente, no plano da verosimilhança. As mulheres insistem na necessidade de pensar um pouco no futuro, porque "não é só de velhice que se morre ... a morte anda pegada à nossa pele" (Machado 1982: 53). Se, como dizem, a morte é inevitável, qual a pressa em inaugurar o cemitério com um defunto estranho? Todo o conto pode ser lido como uma crítica ao artifício, à necessidade de mostrar poder e controlo sobre tudo. Um defunto inaugural por encomenda pode ser facilmente moldado, porque o seu passado desconhecido não interfere na persona em que vai ser transformado. A sua identidade é, assim, desenvolvida para trazer prestígio à povoação: vê-se convertido em marido da professora, homem de bem que deixa saudades. Pelo contrário, se esperassem pela morte efetiva de alguém do povoado para se inaugurar o cemitério, não haveria qualquer controlo sobre as variáveis, pois, neste contexto, a morte é aleatória e imprevisível.

Contudo, a morte estava mais próxima do que todos julgavam, e o próprio narrador tem consciência do cumprimento do seu papel: "Estou sumindo... O espaço emudeceu. Meu prazo terminou” (Machado 1982: 58). A sua permanência em Arraial Novo deixa de ser necessária, porque, 
em breve, alguém da terra vai ser enterrado neste cemitério. No final do conto, os portões abremse para um novo funeral, e o narrador cumpre a função de passagem de testemunho a esta recém-chegada alma a quem, de facto, a "casa” pertence. A identidade dessa pessoa é revelada na última linha do conto: "Entre Dona Maria. Sirva-se do seu cemitério" (Machado 1982: 59). Esta personagem, até então secundária, sem qualquer poder interventivo na história, ganha finalmente destaque. Enquanto esposa do Fundador, cumpriu a sua função terrena de lhe dar mais um filho (morreu pouco depois de dar à luz, provavelmente devido a complicações no parto), contribuindo, assim, para o crescimento populacional de Arraial Novo. Para além disso, a sua função espiritual foi também cumprida: ela é, de facto, a defunta inaugural. A sua morte vem reforçar o absurdo da situação, pois, se as mulheres tivessem deixado a vida correr o seu curso, algum habitante se converteria em defunto para inaugurar o cemitério, mais cedo ou mais tarde.

Por estarem tão ocupadas a preparar o terreno para falecimentos futuros, não conseguiram ver a verdadeira proximidade da morte. Fica uma dúvida: terá sido Fagundes quem, de facto, trouxe a morte para Arraial Novo? Os rapazes e o Fundador acham que sim. Teria Dona Maria sobrevivido se o parto tivesse acontecido antes da chegada do tropeiro, num tempo em que o espírito da morte e a atmosfera sombria ainda não se tinham apoderado do lugar? Estas perguntas não encontram resposta na narrativa; porém, permitem refletir sobre a utilização de elementos insólitos e antinaturais - a figura do narrador póstumo e a ficcionalização de um espaço imune à morte -, para retratar as angústias humanas, muitas vezes reprimidas, como é o caso da angústia de não ter uma última morada onde os corpos pudessem repousar depois de receber os ritos fúnebres cristãos. Terminar a vida nestas condições não asseguraria o descanso eterno da alma. No final, o narrador subverte as regras do estatuto de defunto inaugural, atribuído pela população de Arraial Novo, e reconhece a alma que, de facto, tem o direito de inaugurar o cemitério - uma filha da terra com reputação respeitável, e não um desconhecido anónimo.

\section{Morte e Festa}

Em The Work of the Dead, Thomas Laqueur defende que o desleixo ou a falta de cuidado com o corpo morto é intolerável, pois o cadáver exige a atenção dos vivos e representa a passagem da ordem do natural para a ordem do cultural (Laqueur 2015: 8). Laqueur argumenta ainda que, apesar de o corpo morto ser um objeto insensível, continua a ser cuidado e honrado pelas pessoas que lhe são próximas, e que o tratamento respeitoso dos mortos tem sido largamente reconhecido como um sinal de progresso - o cuidado com os defuntos delimita a fronteira entre a civilização e a selvajaria, entre o nós e o eles (Laqueur 2015: 89). De acordo com este pressuposto, fica esclarecida a necessidade urgente, no conto de Machado, de criar um cemitério em Arraial Novo, porque o povoado não ascenderia à categoria de civilização; iria ficar para sempre aquém das cidades vizinhas. O narrador Fagundes faz referência a alguns comportamentos desrespeitosos para com o seu corpo morto: um cão à procura de ossos quase desenterra a sepultura de Fagundes, e a sua campa é calcada pelos rapazes treinando futebol no cemitério/campo. Contudo, apesar dos pontuais episódios cómicos de desconsideração, o cuidado com o coro reflete o seu valor na sociedade (civilizada) de que fez parte em vida. 
No conto de Aníbal Machado, a vertente etnográfica dos rituais fúnebres fica bastante evidente. O defunto acompanha todo o processo, e uma parte substancial da narrativa centra-se na descrição dos acontecimentos desde a sua morte; é lavado, vestido e exposto a quem quiser prestar-lhe homenagem, até à hora do transporte da igreja ao cemitério para, finalmente, ser sepultado. Neste aspeto, assemelham-se às Memórias Póstumas de Brás Cubas, com a tradição católica das velas, da cruz, do padre e das orações, porque também Brás Cubas assiste aos preparativos do seu velório, procissão fúnebre e enterro (capítulo I, “Óbito do Autor”). Moser descreve o romance de Machado de Assis como um relato etnográfico detalhado da preparação fúnebre e dos costumes de luto do final do século XIX na sociedade brasileira (Moser 2008: 132). "O Defunto Inaugural” pode igualmente ser lido como relato etnográfico dos costumes de luto dos séculos $\mathrm{XX}$, na sociedade rural dos sertões de Minas Gerais, no Brasil.

As respostas a algumas das perguntas de Katherine Verdery sobre os procedimentos necessários para os defuntos descansarem em paz, podem, agora, ser respondidas. Um funeral adequado tem uma série de regras e requisitos que vão afetar as relações entre os vivos e os mortos no espaço social partilhado por ambos (Verdery 1999: 42). Em The Political Lives of Dead Bodies, Verdery questiona, entre outras coisas, quem deve lavar o falecido e como deve ir vestido. No caso do tropeiro Fagundes, estas tarefas são desempenhadas pelas mulheres mais velhas e mais experientes em matéria de funerais. O defunto deve ser enterrado com a sua melhor indumentária - as suas roupas esfarrapadas são trocadas por um fato preto alheio e que lhe fica um pouco grande.

Verdery questiona também depois de quanto tempo, após a morte, deve ser feito o funeral (Verdery 1999: 42). Fagundes é enterrado no dia seguinte ao velório, que dura um dia e uma noite. Contudo, este narrador póstumo tinha sido encontrado na berma da estrada por dois desconhecidos, daí não sabermos há quanto tempo estaria morto antes de chegar a Arraial Novo - apenas que o seu corpo estava muito bem preservado, quase mumificado. Ainda sobre o velório, Verdery pergunta sobre a permissão de beber álcool (Verdery 1999: 42). Fagundes não faz nenhuma referência específica ao consumo de álcool; porém, descreve a festa posterior ao seu funeral como um episódio celebratório. Moser sustenta que, de todos os fantasmas brasileiros trazidos à vida na sua monografia, o narrador póstumo d'“O Defunto Inaugural” é o que mais se aproxima do conceito de defunto carnavalesco (Moser 2008: 65). Morte e festividades não são mutuamente exclusivas no caso deste defunto: o seu velório e procissão fúnebre adquirem contornos normalmente associados a festividades carnavalescas (Moser 2008: 19). Neste conto, o funeral de Fagundes/José é um dia especial em que as regras sociais são subvertidas: as moças podem usar os seus melhores vestidos e namorar com os rapazes sem a constante vigilância das mães, e o resto da população mal consegue disfarçar a sua alegria durante o enterro; a euforia pode depois ser extravasada em risos, abraços, muita comida e bebida.

O defunto é enterrado num espaço da cidade designado especificamente como última morada dos corpos sem vida, de acordo com a tradição católica, com uma missa de corpo presente dita em latim. Fagundes refere ainda um outro símbolo religioso, a cruz colocada sobre a sua campa (retirada pelos rapazes para poderem continuar a jogar futebol, ato sacrílego de acordo com as mulheres do povoado). Verdery questiona o que deve ser dito durante o funeral (Verdery 1999: 42). O discurso elegíaco faz parte da tradição apresentada pelo próprio defunto. Segundo a convenção, os vícios em vida são eliminados das homenagens, porque os mortos merecem apenas elogios - 
Fagundes recebe-os de um desconhecido, o vereador distrital, que fala dele como alguém nascido em Arraial Novo, seu conhecido desde sempre.

Por último, Verdery pergunta o que acontece se algum destes passos não for cumprido corretamente (Verdery 1999: 42). Segundo Moser, as manifestações exteriores de sofrimento e luto fazem parte dos elaborados rituais destinados a ser efetuados aquando da morte de alguém próximo; existe a necessidade de transformar uma má morte (morrer inesperadamente, longe dos entes queridos e sem a oportunidade de conclusão dos assuntos terrenos) numa boa morte (Moser 2008: 18). Alírio teve, de facto, uma má morte, pois morrera sozinho e juntara-se aos muitos corpos anónimos encontrados à beira das estradas. Apesar da solidão da morte, acaba por ser chorado dolorosamente pela viúva que lhe fora atribuída como parte do seu novo estatuto de defunto inaugural de Arraial Novo. Existem assuntos incompletos que amarram o protagonista defunto ao mundo terreno (Bennett 212: 151). Para Fagundes, o ciclo completa-se somente quando passa o testemunho do estatuto de defunto inaugural para dona Maria, a esposa do Fundador, entretanto falecida.

O defunto carnavalesco subverte e desmistifica toda e qualquer forma de autoridade social, política e estética, incluindo a sua própria (Moser 2004: 109). O narrador Fagundes não perde o sentido de humor com a sua condição póstuma e bizarra situação de estar morto e a contar a sua história, ao mesmo tempo que satiriza os costumes e comportamentos dos diversos elementos da comunidade. Fagundes é exemplo de que humor não é sinónimo de alienação ou de escapismo, características atribuídas aos textos fantásticos por Todorov e refutadas por Ana María Barrenechea e Rosemary Jackson. A narração póstuma ilustra o paradoxo entre o controlo exercido por estes defuntos sobre a voz (e as revelações feitas aos leitores) e a total ausência de controlo sobre o corpo que, depois da morte, se transforma em cadáver e perece. Apesar da sua condição não terrena, este narrador defunto continua, ficcionalmente, a habitar o espaço geográfico dos vivos, sendo reconhecido como fazendo parte dessa comunidade de viventes, à semelhança das mulheres defuntas estudadas por Brian Norman em Dead Women Talking (Norman 2013: 3). A pertença a uma sociedade legitima as perspicazes críticas sociais, políticas e religiosas articuladas ao longo das narrativas, através de uma plataforma privilegiada de observação - o ponto de vista póstumo distanciado espacial e temporalmente, que transforma os narradores em figuras de autoridade capazes de revelar segredos pessoais e alheios, numa crítica satírica e bem-humorada da sociedade a que, apesar de ausentes fisicamente, ainda pertencem enquanto espíritos.

A publicação de um livro de memórias póstumas inclui segredos indizíveis entre os vivos, como Brás Cubas fizera; o defunto autor acredita que a sua história de vida contada depois de morrer ganha mais autoridade e, por isso, é a derradeira forma de autobiografia (Bennett 2012: 149). O narrador póstumo do conto de Machado espera pela morte para revelar segredos que tinham permanecido na escuridão da sua mente, até se encontrar numa plataforma distante espacial e temporalmente de todos os constrangimentos experienciados enquanto estava vivo. Podem ler-se vantagens epistemológicas no facto de as suas biografias e as histórias confessadas sobre quem os rodeia serem contadas depois de morrerem, porque podem, agora, olhar retrospetivamente para o que lhes aconteceu e tentar encontrar novos e mais apurados entendimentos para interpretarem a vida que já não têm. Ao darem uma segunda vida aos mortos (no caso específico deste artigo, através da figura do narrador póstumo), os autores dessas ficções conferem-lhes voz, dotando-os de agência para contarem a sua própria história (Holland 2000: 4). Os defuntos podem, assim, es- 
clarecer equívocos, corrigir o discurso de outras personagens, ou revelar factos que tinham ficado silenciados. Nesta minha leitura, os narradores póstumos cumprem a função de confessar segredos pessoais, de satirizar, através do humor, a sociedade em que vivem, e atuar como revisionistas de versões unilaterais da história.

A morte apresenta-se como uma posição dupla: por um lado, é anómala, marginal e reprimida; por outro, é poderosa, central e omnipresente (Bronfen e Goodwin 1993: 19). Nesse sentido, afirmo a relevância do narrador póstumo enquanto figura marginal que conta uma história desconhecida dos vivos - a sua confissão pós-morte ainda tem valor, serve propósitos específicos de revelação de segredos e introdução de motivos de reflexão, possibilitando aos leitores repensar os seus comportamentos ou formas de encarar a realidade. Por todos esses motivos, as obras narradas por defuntos são muito mais que apenas uma declaração de impotência sobre o que não pode ser modificado - ao contrário dos narradores póstumos, que não são capazes de, salvo algumas exceções, alterar a realidade ficcional em que se inserem, os leitores têm a vantagem de conseguir projetar o seu eu no eu que narra, apercebendo-se da sua própria finitude humana e da necessidade de modificar alguns comportamentos, já que, enquanto estão vivos, têm ainda a capacidade de fazê-lo, ao contrário das vozes póstumas aqui referidas. Nesse sentido, a narração póstuma assume uma função didática de retificação de vida.

\section{Referências bibliográficas}

Assis, M. (2014). Memórias Póstumas de Brás Cubas.1881. s/l: Mogul Classics.

Barrenechea, A. M. (1972). Ensayo de una Tipología de la Literatura Fantástica. Revista Iberoamericana, 38 (80), 391-403.

Bennett, A. (2012). Afterlife and Narrative in Contemporary Fiction. Londres: Palgrave MacMillan.

Bronfen, E. (1992). Over Her Dead Body: Death, Femininity and the Aesthetic. Nova Iorque: Routledge.

Bronfen, E.; \& Goodwin, S. W. (Eds). (1993). Introdução. In Death and Representation (pp. 3-25). Baltimore: The Johns Hopkins UP.

Duncan, C. (2010). Unraveling the Real: The Fantastic in Spanish-American Ficciones. Philadelphia: Temple UP. Freud, S. (1997). The Uncanny. In Writings on Art and Literature (pp. 193-233). Stanford: Stanford UP.

Fuss, D. (2003). Corpse Poem. Critical Inquiry, 30 (1), 1-30.

Holland, S. P. (2000). Raising the Dead: Readings of Death and (Black) Subjectivity. Durham: Duke UP. Jackson, R. (1981). Fantasy: The Literature of Subversion. Londres: Methuen.

Kristeva, J. (1982). Powers of Horror: An Essay on Abjection. Trad. L. S. Roudiez. Nova Iorque: Columbia UP. Laqueur, T. W. (2015). The Work of the Dead: A Cultural History of Mortal Remains. Princeton: Princeton UP. Machado, A. M. (1982). O Defunto Inaugural: Relato de um Fantasma. In A Morte da Porta-Estandarte e Tati, a Garota e Outras Histórias (pp. 48-59). 11ª ed. Rio de Janeiro: Livraria José Olympio Editora.

Moser, R. H. (2004). The Carnivalesque Defunto: Death and the Dead in Modern Brazilian Literature. In E. Klaver, (Ed.), Images of the Corpse: From the Renaissance to Cyberspace (pp. 88-112). Portland: The U of Wisconsin P. . (2008). The Carnivalesque Defunto: Death and the Dead in Modern Brazilian Literature. Athens:

Ohio UP. 
Norman, B. (2013). Dead Women Talking: Figures of Injustice in American Literature. Baltimore: The Johns Hopkins UP.

Proença, M. C. (1982). Os Balões Cativos. In A. M. Machado, Morte da Porta-Estandarte e Tati, a Garota e Outras Histórias (pp. ix-xxvi). 11ª ed. Campinas: Livraria José Olympio Editora.

Samósata, L. de. (2007). Diálogos dos Mortos. Trad. H. G. Murachco. Palas Atena.

Snauwaert, E. (2013). El Narrador Póstumo: Figura Innatural e Instrumento de lo Fantástico. In G. Portals Zubiate, \& E. Honores Vasquez (Eds.), Actas del Coloquio Internacional: Fines del Mundo: Narrativas Fantásticas en Hispanoamérica - Coloquiofanperú 2012 (pp. 185-195). Lima: El Lamparero Alucinado Ediciones.

Tavares, T. R. (2012). Religiosidade e Morte no Interior de Minas Gerais. Teoria e Cultura. 7 (1-2), 91-101.

Todorov, T. (1973). The Fantastic: A Structural Approach to a Literary Genre. Cleveland: Press of Case Western Reserve University.

Verdery, K. (1999). The Political Lives of Dead Bodies: Reburial and Postcolonialist Change. New York: Columbia UP. 